\title{
GOOD FAITH AND EVICTION CONTROL: A CASE STUDY IN ADMINISTRATIVE ACCOMMODATION
}

\author{
TOBIAS WEISS $\dagger$
}

EFFECTIVE regulation of eviction, made necessary by the acute housing shortage after the war, required an empowering statute sufficiently flexible in its terms to enable the executing agency to deal with the numerous arrangements invariably contrived to render inert restrictions ${ }^{1}$ accompanying controls. Power to promptly meet potentially disruptive developments before they took substantial shape was especially valuable because the occasion for regulation was an emergency and hence even slight dislocations might materially aggravate an already critical situation and cause considerable hardship. Provision for such power had of necessity to be general, the field regulated being comparatively uncharted and replete with numerous problems which could not be foreseen with any measure of particularity. ${ }^{2}$

When the federal Housing and Rent Act of 1947 relaxed eviction controls on residential accommodations, ${ }^{3}$ the local legislature in New York City found that a "serious emergency exists in New York by reason of the shortage of apartments. Unless evictions from such accommodations are regulated, disruptive practices and abnormal conditions will produce serious threats to the health, safety and general welfare of the inhabitants of the city. Action by local law is necessary to prevent chaos and confusion resulting from such disruptive practices." 4 To cope with this emergency, the local legislature imposed a general prohibition against evictions. A limited number of exceptions were specified, however. One such exception was made where "the landlord because of compelling necessity, seeks in good faith to reccver possession of such apartment for his own immediate and personal use and occupancy as dwelling accommodations." $\mathrm{A}$ rent commission was created to carry out the enact-

† Member of the New York Bar.

1. See Matter of Cole v. Coster, 122 N.Y.L.J. 1627, col. 3 (Sup. Ct. Dec. 13, 1949). See also Commissioner Herbert Wechsler's provocative comment, Next Steps In Rent Control, 5 The Record of the Assoc. of the Bar of the City of New York 126 (1950).

2. Cf. Gellhorn, Admisistrative Law Cases and Comment 158 (2d ed. 1947).

3. 61 Stat. 193 (1947) 50 U.S.C.A. App. $\$ 18 \$ 1$ (Supp. 1948); see Willis, The Fcderal Housing and Rent Act of 1947, 47 CoL. L. Rev. 1118, 1134 (1947) ; FinaL Report of the Temporary City Housing Rent Comisission to the Mayor of the City of New York, Control of Evictions and of Residential Rents By New York CITY 4 (1950) (hereinafter referred to as the Final Report).

4. Declaration of policy in New York City Local LAw No. 66 of 1947, adding § U417.0 to the Administrative Code of New York City; $c f$. declaration of purpose in D.C. Code 45-1601 (1940).

5. N.Y.C. ADMrn. Code, $\S U 41-7.0$ (c) (2), as amended by N.Y.C. Local Law No. 12 of $1948, \S 1$. This exception was responsible for the great majority of applications for certificates of eviction. FINAL REPORT 15. The other exceptions, provided as grounds for eviction upon certification by the commission, were as follows: (1) Violation of an 
ment. Certification by it that a landlord satisfied one of the statutory exceptions was required before he was allowed to bring an eviction proceeding in court.

This law, like other eviction controls which have used the term, ${ }^{6}$ did not expressly define "good faith." The term can be used with variety in meaning under a varying range of circumstances. "While it clearly implies absence of deceit or dishonesty, its meaning may extend beyond these minimal limits. ${ }^{8}$ The task remained for the commission, subject to review by the courts, to plot the area of intended meaning for eviction control purposes. The process was one of definition through application, for which legislative guidance was not completely lacking. There was the background and purpose of the law, about which the declaration quoted above appeared in the statute, ${ }^{9}$ and there was the scheme of the law, showing an intention not to disturb the freeze in tenancies except in narrowly limited situations. This background of intent was

obligation of the tenancy, other than an obligation to pay more than the maximum rent or to surrender possession. (2) Commission of a nuisance, or use of the apartment for illegal or immoral or other than dwelling purposes. (3) Alteration or demolition of the premises under specified circumstances. (4) Occupancy of non-housekeeping furnished accommodations in a dwelling which was not in a boarding house and the remainder of which was occupied by the landlord or his immediate family. N.Y.C. ADMrns. CoDE, $\$$ U41-7.0 (c). This law was thereafter reenacted by N.Y.C. LoCAL LAW No. 41 of 1948, N.Y.C. Local Law No. 7 of 1949, N.Y.C. LocaL Law No. 22 of 1949, and N.Y.C. LOCAL LAW No. 73 of 1949.

For the comparable provisions under federal controls, see:

(1) Under OPA controls, enacted by the Emergency Price Control Act of 1942, 56 Stat. 23 (1942), as amended, 50 U.S.C.A. App. $\$ \S 901$, 902(d) (Supp. 1950): Eviction Reg. I, §1388.532(a) (6), 7 FED. REG. 9133 (1942); Maximum Rent Reg. 60, $\$ 1388.786$ (a) (6), 7 FED. REG. 10452 (1942); Rent Reg. for Housing $\$ 1388.1181$ (6) (a) (6), 8 FED. REG. 14668 (1943). The last mentioned regulation appeared thereafter, as amended, in 9 FED. REG. 11340 (1944), 10 FED. REg. 3441 (1945), 10 FED. REG. 13533 (1945), 11 FED. REG. 12061 (1946). These controls were initially taken over by the OHE after the OPA was abolished. 12 FED. REG. 2986 (1947).

(2) Under the Housing and Rent Act of 1947, supra note 3, § 209, amended by the Housing and Rent Act of 1948, 62 STAr. 93 (1948), the requirement of a certificate of eviction was removed, and control of evictions placed entirely in the courts.

(3) The Housing and Rent Act of 1949, Pub. L. 31, 81st Cong., 1st Sess. $\$ 206$ (Mar. 30, 1949), amending the Act of 1947, restored control of evictions to the Housing Expediter, who then issued $\$ 825.6$ of the Controlled Housing Rent Reg., 14 FED. REG. 1572 (1949).

6. See notes 4 and 5 supra for the District of Columbia and federal controls respectively.

7. Compare, e.g., 11 U.S.C. $\$ 541,546$ (1946) (corporate reorganization), with Labor Management Relations Act of 1947, 29 U.S.C. $\$ 158$ (d) (Supp. 1949).

8. See, e.g., In re Paloma Estates, Inc., 126 F. $2 \mathrm{~d} 72$ (2d Cir. 1942), cert. denied, 317 U.S. 684 (1942) ; N.Y. Times, July 25, 1950, p. 30, col. 8 (lack of good faith in collective bargaining).

9. See note 4 supra. 
significant in any case of doubt.10 The commission's task was further directed by the need for interpretation which would give effect to all the statutory provisions and left none superfluous. ${ }^{11}$ Finally, in retrospect, the validity of an interpretation might be tested to some extent by the action of the legislature in later considering amendment or reenactment of the law. ${ }^{12}$

Hundreds of cases came before the commission in which "good faith" was in controversy. In each case resolution of the issue depended on the particular facts and circumstances. Yet, with experience, most cases fell into distinctive patterns. The manner in which the commission disposed of these cases represented an administrative agency's effort to adjust itself to the environment of its operation. In the process, a concept of good faith emerged.

\section{MisRepresentation}

The situations in which the commission found occasion to apply the good faith requirement embraced several broad categories. The first of these involved misrepresentation or dishonesty by landlords respecting legal prerequisites for the issuance of a certificate of eviction.

Misrepresentation might be made in regard to particularized or "immediate" facts, as, for example, the number of people comprising the landlord's family. Proof of some of these immediate facts, such as payment of a specified minimum portion of the purchase price in cash, was expressiy required by the local law. ${ }^{13}$ Other immediate facts were asserted by landlords not as ends in themselves but in order to lay a foundation for an "ultimate" fact, which the law required as a condition to a tenant's eviction. One such ultimate fact was the requirement of compelling necessity, constituting a conclusion drawn from a complex of immediate facts.

That there had been misrepresentation might be established by proof which directly contradicted material allegations of the landlord. Thus, where a landlord claimed he was living in his parents' three-room apartment, misrepresentation, and consequently bad faith, was shown by proof that the landlord and his

10. See, e.g., Chittenden Lumber Co. v. Silberblatt \& Lasker, Inc., 288 N.Y. 396, 402-3, 43 N.E. $2 d 459,462$ (1942); 2 Sutherland, Statutory Construction $\$ 4704$ (3d ed. 1943) ; cf. Cardozo, J., dissenting in Panama Refining Co. v. Ryan, 293 U.S. 388, 433 (1935).

11. See Abbot v. Bralove, 176 F. 2 d 64, 66 (D.C. Cir. 1949); Sutherland, op. cit. supra note $10, \S 4705$.

12. See Matter of Gilmore v. Preferred Accident Ins. Co., 283 N.Y. 92, 97, 27 N.E. 2d 515, 517 (1940). Reconsideration of emergency legislation after its enactment is to be expected in view of the strong public interest. This was true of both local and federal controls. See note 5 supra.

13. The local law required, where the landlord sought a certificate based on compelling necessity, that he establish payment "to the seller, in cash, at least 20 per cent of the purchase price under such sale or contract of sale, or 20 per cent of the assessed value of the land and the entire building or structure thereon, whichever shall be greater." N.Y.C. ADMIn. CODE $\S U 41-7.0$ (i). Federal controls have a comparable requirement of $10 \%$. Controlled Housing Rent Reg., $\$ 825.6$ (c) (1) (c), supra note 5. 
parents in fact lived in nine, and not three, rooms. ${ }^{14}$ The sole adjudicatory problem here presented was that of evaluating and comparing the probative force of the conflicting evidence. ${ }^{15}$ It was in such cases-direct proof of misrepresentation of immediate facts-that there was the least controversy in applying the requirement of good faith.

Proof of misrepresentation might, however, depend on circumstantial evidence from which an inference might be drawn disproving allegations of the landlord. The assertions so contradicted might be either of immediate or ultimate facts. Here too there was the question of the probable truth of the evidence introduced. ${ }^{16}$ But even assuming the existence of the circumstantial facts contended for, there was the additional problem of the sufficiency of these facts as a basis for the inference sought to be made. The validity of the inference under such circumstances was the source of frequent and serious dispute.

\section{a. Compelling Necessity}

The local law as first enacted did not expressly require a showing of compelling necessity; like the federal eviction controls then in effect, ${ }^{\mathbf{1 7}}$ it provided for issuance of a certificate where the landlord sought in good faith to recover possession of accommodations for his immediate housing use. ${ }^{18}$ The commission, however, required a showing of compelling necessity as a condition to the proof of good faith. This was held in a number of cases to be unauthorized under the statute and beyond the commission's powers. ${ }^{19}$ The law was then amended, as the rent regulation of the OPA earlier had been, ${ }^{20}$ to require such a showing explicitly. ${ }^{21}$ It became incumbent upon the landlord to affirm in his application the circumstances showing the ultimate fact of compelling necessity.

14. Matter of Ladolcetta v. Finkelstein, 120 N.Y.L.J. 336, col. 3 (Sup. Ct. Aug. 30, 1948). Cf. Matter of Curreri v. Coster, 122 N.Y.L.J. 825, col. 1 (Sup. Ct. Oct. 13, 1949) (landlord lived in six rooms and not in cellar as alleged); Matter of Mangiolomini v. Coster, 121 N.Y.L.J. 929, col. 5 (Sup. Ct. Mar. 14, 1949) (misrepresentation as to availability of accommodations adequate to relieve landlord's need). Similarly as to consideration paid by the landlord for the premises. Matter of Bailey v. Coster, 121 N.Y.L.J. 1056, col. 3 (Sup. Ct. Mar. 23, 1949).

15. E.g., Matter of Sevin v. Temporary City Housing Rent Commission, 120 N.Y.L.J. 219, col. 1 (Sup. Ct. Aug. 9, 1948).

16. See Janise v. Bryan, 89 Cal. App.2d 933, 941, 201 P. $2 d$ 466, 472 (1948).

17. Section 209 (a) (2) of the Housing and Rent Act of 1947, supra note 3.

18. N.Y.C. LoCAL LAw No. 66 of 1947, supra note 4.

19. E.g., Matter of Wallach v. Ross, 119 N.Y.L.J. 1034, col. 7 (Sup. Ct. Mar. 19, 1948), rev'd, 273 App. Div. 1021 (2d Dep't. 1948), aff'd, 298 N.Y. 806, 83 N.E. 2d 700 (1949); Matter of Lawrence v. Ross, 191 Misc. 88 (Sup. Ct. 1948), rev'd, 274 App. Div. 781 (1st Dep't. 1948).

20. OPA Rent Reg. For Housing $\S 6$ (a) (6), supra note 5, as amended Sept. 15, 1945, 10 FED. REG. 11667 (1945) (landlord "has an immediate compelling necessity to recover possession of such accommodations for use and occupancy as a dwelling for himself"); see Lakowski v. Kustohs, 328 IIl. App. 557, 66 N. E. $2 d 487$ (1946).

21. N. Y. C. LOCAL LAW No. 12 of 1948, supra note 5. 
Landlords whose circumstances failed to meet the exacting standards of need followed by the commission, ${ }^{22}$ might misrepresent their housing position. Such misrepresentation might be established, as has been observed, through direct contradiction of material immediate facts asserted by the landlord, such as the nature of his quarters or the size or composition of his family. But proof of misrepresentation might depend rather on the circumstantial process. Thus, in Matter of Shidiack $v$. Finkelstein, ${ }^{23}$ a certificate was sought by a landlady who lived alone in a second-floor apartment consisting of six rooms. She was 51 years of age, and claimed that the effects of a menopause syndrome made it hazardous for her to climb stairs. She sought to evict a tenant who lived in a first-floor apartment of seven rooms. In opposition, it was shown that the landlady used the subway daily in travelling to and from work in a garment factory, and that the tenant received a notice to move shortly after he had inquired of the Housing Expediter about painting requirements. The commission denied the certificate and was sustained on judicial review.

In this case there was no direct proof that the landlady had misrepresented her need. Instead circumstantial proof was used to establish two inferences: (1) The landlady's mode of living showed there was no compelling necessity either because she did not have the claimed illness or, if she did, it was not so serious that she was unable to climb stairs safely. (2) The landlady's motive in seeking a certificate was not relief of a compelling necessity but retaliation against the tenant. This was typical of circumstantial attacks on allegations of compelling necessity. ${ }^{24}$

\section{b. Improper Motive or Purpose}

The permissible purpose in seeking a tenant's quarters was narrowly limited, even where an express requirement of compelling need was absent, as has been true for most of the time under federal controls, even in the absence of an express requirement of compelling need. It was not enough that the landlord was under a compelling need or that he actually intended to use the premises as a dwelling, and that these were factors influencing his decision to obtain the tenant's eviction. It was required, in addition, that he be motivated by a desire to possess the premises rather than to dispossess the tenant. The required motive not only had to exist as a responsible cause but had to be the dominating inducement behind the landlord's application. An intent otherwise legitimate but born of a desire to dispossess nonetheless

22. See Final Report 15-19; Matter of Keller v. Finkelstein, 274 App. Div. 932 (2d Dep't 1948) ; cf. the statements of Commissioner Herbert Wechsler in minutes for the commission's 134th Executive Meeting, May 10, 1949, and the 158th Executive Meeting, Nov. 29, 1949.

23. 120 N.Y.L.J. 1410 , col. 5 (Sup. Ct. Dec. 6, 1948).

24. Cf. Matter of Slovikowski v. Coster, 276 App. Div. 971 (2d Dept 1950); Matter of Kennedy v. Coster, 275 App. Div. 1057 (2d Dept 1949). 
disqualified him. ${ }^{25}$ Limitation on motive applied likewise to other, less frequently used, grounds for eviction besides that of owner-occupancy. ${ }^{26}$

The disqualifying motives most frequently encountered were found to embrace two broad categories:

(1) Retaliation against the tenant. The presence of this motive was usually indicated by a history of bad relations between landlord and tenant. ${ }^{27}$ While the inference drawn from such a background was, of course, to be determined by the total context in which it was set, ${ }^{28}$ circumstantial evidence relating friction to the eviction attempt was generally enough to bar the tenant's removal. ${ }^{29}$ When the friction was the result of the tenant's insistence on his rights under rent controls, the landlord could succeed only after a very clear showing that he was not motivated by vengeance. ${ }^{30}$

(2) Profit. The desire for more money did not entitle a landlord to an eviction certificate, ${ }^{31}$ and disguise of this motive constituted bad faith. The landlord failed where it was shown that he sought to evict in order to get above-ceiling rentals. ${ }^{32}$ Similarly, both local law and OPA controls forbade eviction in order to profit from a sale of the premises. ${ }^{33}$ Evidence proving

25. See e.g., Gibson v. Corbett, 87 Ca1. App. 2d 926, 932, 200 P. 2d 216, 220 (1948); Matter of Anthony Lancieri, 4 Pike \& Fischer, OPA OPS. \& Dec. 3321, 3323 (OPA 1946). This set of PIKE \& FISCHER reports will hereinafter be referred to as P \& F.

26. Examples are eviction for the purpose of altering or converting accommodations inhabited by the tenant, see note 5 supra; also, e.g., $\$ 209$ (a) (4), Housing and Rent Act of 1947, note 3 supra, and eviction for the purpose of withdrawing the premises from the rental market, e.g., $\$ 209$ (d), Housing and Rent Act of 1948, 62 SтAт. 93 (1948). The local law was held constitutional in denying eviction designed to effect withdrawal from the rental market. Loab Estates, Inc. v. Druhe, 300 N. Y. 176, 90 N. E. 2d 25 (1949).

27. E.g., Matter of Taschler v. Finkelstein, 120 N.Y.L.J. 1526, col. 7 (Sup. Ct. Dec. 14, 1948). Cf. McSweeney v. Wilson, 48 A. 2 d 469 (D. C. Mun. Ct. App. 1946) (friction following application for certificate of only slight evidentiary value).

28. See Colwell v. Stonebraker, 31 A. 2d 866, 867 (D. C. Mun. Ct. App. 1943).

29. E.g., under federal controls, Matter of Vincenso Piacente, 5 P \& F 3079 (OPA 1946) (coincidence between dates of tenant complaint and landlord's petition for eviction certificate); Matter of Abe Yeselson, 3 P \& F 3472 (OPA 1945) (failure to move sooner to remedy a long-existing alleged need); Lelek v. Baker, 309 Mich. 210, 14 N. W. 2d 838 (1944) (previous attempts to evict).

30. See, e.g., Matter of Rose Barotz, 3 P \& F 3164, 3169 (OPA 1945).

31. See Gould v. Butler, 31 A. 2 d 867, 869 (D. C. Mun. Ct. App. 1943). Serious enough financial straits might justify the landlord's action. E.g., Matter of Perrone v. Coster, 121 N.Y.L.J. 1566, col. 4 (Sup. Ct. May 2, 1949).

32. E.g., Matter of De Land Holding Corp., 4 P \& F 3128, 3129 (OPA 1946). Cf. Carrow v. Bishop, 50 A. 2d 598 (D. C. Mun. Ct. App. 1946) (reliance on need for alterations).

33. E.g., Matter of Bloomfield v. Finkelstein, 120 N.Y.L.J. 432, col. 7 (Sup. Ct. Sept. 14, 1948) (local law); Matter of Bernard J. Zuneska, 5 P \& F 3298 (OPA 1947). 
an intent to sell ordinarily resulted in denial of a certificate, ${ }^{34}$ unless some reason other than profit were shown for the desire to sell. ${ }^{35}$

There were occasions when landlords candidly admitted a disqualifying motive. Thus, under OPA controls, one landlord testified in court that "rather than have any question about the rent, I preferred to move in there myself,"3e and another had assured the tenant that she was going to evict him for "making trouble with OPA."37 It became evident, however, that applications in which such confessions were made had little chance of success regardless of the accompanying trappings. In doubtful cases, therefore, disguise was preferred to disclosure. The common practice was for landlords to confine their applications to a showing of a permissible underlying motive, even though making the showing entailed distortion or dishonesty. The deceptive facade might consist, for example, of an alleged desire to protect health, or to obtain space for a janitor. ${ }^{38}$ In such circumstances the tenant's opposing papers characteristically charged suppression of an improper purpose. $^{39}$

When this occurred, the tenant had to depend on circumstantial evidence to prove his point. The range of evidence was necessarily broad. Thus, although there might be no obligation on the landlord to exchange apartments with the tenant, ${ }^{40}$ refusal to make an exchange was one of the totality of facts which might bear on motive, ${ }^{41}$ and once made an offer of exchange might by its terms provide evidence of bad faith. ${ }^{42-43}$

Difficult cases arose where there were a number of occupied apartments the possession of any one of which was adequate to relieve the landlord's need. The local law at its outset did not expressly require him to proceed

34. See Matter of Bernard Zuneska, supra note 33, at 3299; cf. Matter of Elberg v. Coster, 123 N.Y.L.J. 1131, col. 4 (Sup. Ct. Mar. 30, 1950) (intent to sell shown by public offer).

35. Cf. Matter of Logan v. Finkelstein, 120 N.Y.L.J. 1410, col. 5 (1949).

36. Brown v. Wood, 59 F. Supp. 872, 873 (N. D. Cal. 1943).

37. Matter of Eva Broch De Rotherman, 5 P \& F 3083, 3084 (OPA 1946).

38. See, e.g., under OPA controls, Lakowski v. Kustohs, supra note 20 (health); Matter of Vincenso Piacente 5 P \& F 3079 (OPA 1946); cf. Matter of Joseph Friedman 5 P \& F 3127 (OPA 1946) (janitorial accommodations).

39. Often no adequate proof of the tenant's position was available until after granting of the application. Cf. Nyulassie v. Mozer, 85 Cal. App. 2d 827, 193 P. $2 \mathrm{~d} 167$ (1948); Kauffman \& Sons Saddlery Co. v. Miller, 298 N. Y. 38, 80 N. E. 2d 322 (1948). This raised the problem of the power to reconsider the application. E.g., Matter of Niesen v. Coster, 276 App. Div. 1076 (1st Dep't 1950).

40. It was held that the commission could not compel an exchange under the good faith reguirement. Matter of Anderson v. Coster, 122 N.Y.L.J. 305, col. 1 (Sup. Ct. Aug. 22, 1949). The commission acquiesced in this decision. See statement by Commissioner Herbert Wechsler, Item IVc of Minutes of 163d Executive Commission Meeting, Jan. 17, 1950.

41. See Nofree v. Leonard, 327 IIl. App. 143, 148-9, 63 N. E. 2d 653, 656 (1945).

42-43. Cf. Matter of Shapiro v. Finkelstein, 120 N.Y.L.J. 1257, col. 3 (Sup. Ct. Nov. $23,1948)$. 
against one tenant rather than another. Although restrictions later confined him to the course which would cause the least hardship, ${ }^{44}$ the choice between apartments otherwise remained that of the landlord. ${ }^{45}$ The selection might, of course, indicate an improper motive. ${ }^{46}$ But if his motivation in deciding to repossess an apartment were proper, the landlord seemed free to choose the apartment most advantageous to him.

\section{EvasToN}

In the situations so far treated, the gravamen of the misconduct was the practice of deception or dishonesty in the application to the commission. The effort was essentially at evasion through deception in the application. There was little doubt that such misconduct, where established, negatived good faith.

In the cases now to be discussed, no deceit in the application itself to the commission was necessarily present. The lack of good faith lay rather in behavior prior to the application. Even where there was full disclosure of fact in the landlord's application, good faith was infringed in these cases because of prior conduct designed to circumvent restrictions in the law by achieving through indirection what was forbidden by more direct means. It was in this area that the commission applied a concept of good faith especially indigenous to eviction control, and it was here that there was the greatest dispute over the commission's interpretation of good faith.

\section{a. Self-Created Or Self-Contimued Need}

The commission did not believe that its duty to inquire ended with the mere existence of compelling necessity, without regard either to the manner in which the need arose or the cause responsible for its continuation. ${ }^{47}$ If a need, brought into being at will or through substantial contribution by a landlord, sufficed to deprive a tenant of his living quarters, the joint aims of protection of tenants and stabilization of housing conditions might well be undermined. Tenants would then be assured of stability of living conditions only under

44. The law was amended to authorize eviction only from the apartment containing the fewest occupants. Local Law 84 of 1948; Local Law 7 of 1949; Local Law 41 of 1949. The provision was allowed to lapse in Local Law 73 of 1949. There was some question of the city's power to enact the requirement. Cf. F. T. B. Corp. v. Goodman, 300 N. Y. 140,89 N. E. $2 d 865$ (1950). And the commission was dissatisfied with the presumption of a correlation between hardship and the number of occupants in an apartment. After Local Law No. 73, therefore, the commission issued a regulation permitting eviction only of the tenant who would suffer least hardship. Amendment II to Reg. II, Art. 2 \$ (b) (1) (Feb. 10, 1950); see FinaL RePort 22-3.

45. See Item Vc of Minutes of 158th Executive Commission, Nov. 29, 1949. See, e.g., Rhodes v. Allen, 89 Cal. App. 2d 933, 944, 201 P. 2d 466, 473-4 (1948).

46. See, e.g., Chairman Coster's statement in Minutes, sulpra note 45.

47. See statements of Commissioners Wechsler, Sorkin, and Coster, Item IX of the 168th Executive Commission Meeting, Feb. 24, 1950. 
very limited circumstances. In essence, there would be added as grounds for eviction as many causes as might prompt a landlord to seek a tenant's eviction and might therefore be responsible for the creation or continuation of a need.

An example of this type of control arose in Matter of Engel v. Finkelstein. ${ }^{48}$ The landlady lived in an adequate apartment in a house owned by her sister, but wanted to repossess her own house. To achieve this she consented to issuance of an order of eviction against her in a summary proceeding brought by the sister. Then, asserting a need for housing, she applied for a certificate. The commission found the need to be self-created, and good faith therefore not established. The Appellate Division sustained, holding the commission's determination to have been a proper exercise of its discretion. Similarly, in Matter of Imber $v$. Coster, ${ }^{49}$ the landlord exchanged an adequate apartment for an inadequate one, the limitations of which he knew at the time of the exchange. In sustaining denial of a certificate, the reviewing court found that it was safe to assume that the legislature did not intend a certificate to issue under such circumstances. ${ }^{50}$

A voluntary sale by a landlord of the premises at which he resided was an alternative method of surrendering satisfactory quarters. Compelling necessity resulting from such a disposition did not justify granting a certificate. As noted above,51 a tenant's eviction could not be obtained just to put the landlord in a better position to sell the premises. There seemed to be little distinction in substance between that situation, where the tenant lived in the house to be sold, and the situation in which instead the landlord lived there. The tenant's eviction appeared equally in both situations to do no more than facilitate the landlord's sale. Denial of a certificate under such circumstances was sustained by the Appellate Division in Matter of Clemente v. Finkelstein, ${ }^{52}$ and in numerous cases by the lower courts. ${ }^{53}$

Besides creating his own need, a landlord might show lack of good faith by unnecessarily continuing a validly created need. For example, lack of good faith was found and certificates denied where a vacant suitable apartment was rented out instead of being occupied by the landlord ;54 where he obtained a

48. 275 App. Div. 779 (2d Dep't 1949).

49. 123 N.Y.L.J. 1285, col. 1 (Sup. Ct. Apr. 12, 1950).

50. Federal controls have not required compelling necessity as a condition for eviction, except for a brief interlude under OPA regulation. See notes 5 and 20 supra. No "selfcreated need" doctrine was developed. See Lester v. Beer, 74 Cal. App. 2d 984, 990, 168 P. 2d 998, 1002 (1946).

51. See note 33 supra.

52. 274 App. Div. 1069 (2d Dep't 1949).

53. E.g., Matter of Zabriskie v. Finkelstein, 121 N.Y.L.J. 1001, col. 4 (Sup. Ct. Mar. 18, 1949).

54. E.g., Mangiolomini v. Coster, 121 N.Y.L.J. 929, col. 5 (Sup. Ct. Mar. 14, 1949). Compare Commissioner Wechsler's comment, Item IIIb of Minutes of 131st Executive Commission Meeting, Apr. 19, 1949, apparently attempting to draw a distinction between 
certificate and then sold the house concerned instead of proceeding to satisfy his need by evicting the tenant; ${ }^{55}$ and where he refused another tenant's offer to make adequate space available to him..6 Similarly, refusal to exchange accommodations, might result in a disqualifying self-continued need.57

The need asserted by a landlord very often was created or continued in order to provide housing space for persons other than himself or members of his family unit. Married children, parents and other relatives were typical objects of his bounty. The local law prohibited issuance of certificates to landlords for the benefit of such persons, ${ }^{58}$ and analogous, although less stringent, restrictions have been adopted in other eviction controls. ${ }^{69}$ Landlords attempted to evade this prohibition by allowing them to use accommodations he could have occupied himself, and then alleging his own resulting need as a basis for obtaining other accommodations. Such efforts were unsuccessful where the landlord either had failed to move into an available apartment ${ }^{60}$ or had vacated one. ${ }^{61}$ In other cases the landlord allowed relatives to move with him into an available apartment, and then claimed compelling necessity because of overcrowding. Thus, in Matter of Urgo v. Coster, ${ }^{62}$ a son, who was engaged to be married, bought a house in which a five-room apartment was vacant. His brother and sister-in-law moved in with him and his parents, who had already been living with him. Shortly afterwards the son married, and then applied for a certificate. Denial on the ground of lack of good faith was sustained by the Appellate Division. The same result

passive non-action and affirmative action. This statement construed the self-created need principle more narrowly than the later expressions cited note 47 supra.

55. Matter of Galati v. Coster, 121 N.Y.L.J. 1296, col. 1 (Sup. Ct. Apr. 11, 1949).

56. E.g., Matter of Ingegno v. Coster, 122 N.Y.L.J. 1505, col. 6 (Sup. Ct. Dec. 5, 1949).

57. E.g., Matter of Knappe v. Coster, 122 N.Y.L.T. 1014, col. 7 (Sup. Ct. Oct. 27, 1949). 1948).

58. See note 5 supra; Matter of Prete v. Finkelstein, 274 App. Div. 905 (2 Dep't

59. See Housing and Rent Act of 1948, $\$ 204$ (a), supra note 5 (permitting eviction for the landlord's own occupancy or "a member or members of his immediate family"); N. Y. Laws of 1950, c. $250, \S 12$ (f) (similar limitation) and the regulation thereunder, Rent and Eviction Reg. of N. Y. State Temporary Housing Rent Commission (1950), $\S 55$ (1) (defining "immediate family" to include only a son, daughter, father or mother); Cicchino v. Biarsky, 26 N. J. Misc. 300, 61 A. $2 d 163$ (1948). The "immediate family" restriction did not exist in the OPA regulations and the Housing Rent Act of 1947, and decisions under those controls allowed landlords to recover possession for other than their own personal use. See, e.g., Di Paola v. Seppala, 336 Ill. App. 344, 83 N. E. 2d 889 (1949); Ucci v. McBrian, 190 Misc. 14 (City Ct. 1947); but cf. Lelek v. Baker, 309 Mich. 210, 14 N. W. 2d 838 (1944); OPA Interpretation 6(b) (2)VIII (3), 12 Fed. REg. 123 (1947).

60. E.g., Matter of Gardella v. Ross, 274 App. Div. 889 (2d Dep't 1948).

61. E.g., Matter of Calabro v. Coster, 90 N.Y.S. 2d 344 (Sup. Ct. 1949).

62. 275 App. Div. 951 (2d Dep't 1949). See also, e.g., Matter of Vinti v. Finkelstein, 275 App. Div. 956 (2d Dep't 1949). 
followed where the landlord permitted relatives to move into an apartment in which he was already residing. ${ }^{63}$

Conduct creating or unnecessarily continuing a compelling necessity, however, did not invariably defeat an application. The landlord might justify his conduct, or establish that it was not designed to be evasive. ${ }^{64}$ For example, sale of a house while the owner was confined to a mental hospital without apparent prospect of release would not preclude an application for a certificate made after discharge from the institution. ${ }^{65}$ In a number of cases a landlord justified disposition of suitable living facilities by showing a reasonable expectancy that other quarters would become available. ${ }^{66}$

Assuming debarring conduct without justification at some time in the past, the question arose how long the landlord was to remain disqualified on that account. In the Urgo case denial of a certificate was made a year after the conduct in question. ${ }^{67}$ In some instances, longer intervals had elapsed. ${ }^{68}$ Where, however, there is a break in the causal chain between the condemned conduct and the need on which the application is based, the conduct would no longer seem to be a bar to obtaining a certificate. For example, the need responsible for the application may be significantly different from the one that was self-created and may have arisen from independent circumstances. ${ }^{69}$ A proximate cause rationale seems a reasonable way of limiting the effect of the banned conduct even where the chain of physical causation remains unbroken. Past misconduct should not be deemed the proximate cause of the landlord's plight where consideration of all the circumstances, in view of the control program, makes it equitable to cut short the landlord's need. ${ }^{70}$

\section{b. The Seller-In-Possession Problem}

A substantial part of the housing subject to local controls consisted of quarters in small homes in which the owners resided. According to the 1940

63. E.g., Harmis v. Coster, 123 N.Y.L.J. 295, col. 3 (Sup. Ct. Jan. 24, 1950). Cf. N. Y. Times, July 21, 1950, p. 4, col. 5.

64. See statement of Commissioner Wechsler, Item IX of Minutes of 168th Executive Commission Meeting, Feb. 24, 1950; statements cited in note 47 supra.

65. Matter of De Mori v. Finkelstein, 121 N.Y.L.J. 107, col. 5 (Sup. Ct. Jan. 10, 1950). Cf., e.g., Matter of Esposito v. Wechsler, 121 N.Y.L.J. 1711, col. 6 (Sup. Ct. May 12, 1949) (giving up of quarters during separation; application after reconciliation approved); Matter of Tonetti v. Coster, 121 N.Y.L.J. 1525, col. 4 (Sup. Ct. Apr. 28, 1949) (surrender of quarters due to sale of business).

66. E.g., Menahem v. Coster, 88 N.Y.S. 2d 509 (Sup. Ct. 1949).

67. Note 62 supra. The landlord bought the house in question in November 1947. He applied for a certificate in September 1948. The commission denied the application in December 1948. See the record on appeal, folios 51-7 and 100-104.

68. Matter of Meissner v. Finkelstein, 120 N.Y.L.J. 888, col. 7 (Sup. Ct. Oct. 22, 1948) (2 years) ; Matter of Zabriskie v. Finkelstein, 121 N.Y.L.J. 1001, col. 4 (Sup. Ct. Mar. 18, 1949) ( $1 \frac{1}{2}$ years).

69. Cf. Matter of Doran v. Coster, 123 N.Y.L.J. 1052, col. 6 (Sup. Ct. Mar. 24, 1950). 70. See Matter of Aluisi v. Finkelstein, 82 N.Y.S. 2d 569, 570 (Sup. Ct. 1948). 
census statistics for New York City, owners dwelled in 90,157 two-family houses and 24,204 three-family houses, as well as in a considerable number of small homes with a larger number of apartments. ${ }^{71}$ The post-war housing shortage produced a boom market in such properties. ${ }^{72}$ Unprecedented real estate prices offered strong inducement to owners of pre-war houses to sell out at a sizable profit. The rent control acts gave added stimulus to this trend by restricting the extent to which the housing shortage could be exploited to enhance income. One large deterrent to any sale, however, was the fact that the sellers would themselves become exposed to the shortage. ${ }^{73}$

The seller-in-possession device was developed to eliminate this obstacle. Because of the great demand for housing, a prospective seller was able to insist that the buyer agree to leave the seller in possession of the rooms he occupied. This caused the buyer, in order to satisfy his own housing need, to seek the eviction of a tenant. Under such an arrangement the sale was consummated at the expense of the tenant-he was to be put out so that the seller might realize his inflated profit without loss of possession. The threat of eviction by this method, moreover, could be used to obtain concessions in violation of the emergency controls. ${ }^{74}$

To permit such arrangements would have promoted evictions and threatened the housing security of a large number of tenants. If an owner desired to capitalize on the current inflated market, he, rather than the tenant, should bear the hazards involved in surrender of pussession. Fixing the risk in this manner would limit such sales to situations where the sellers had provided for their own future housing needs, ${ }^{75}$ thus keeping to a minimum the disruptive effect on the housing situation.

The commission considered seller-in-possession arrangements to be contrary to the aims of the emergency law to protect tenants and stabilize housing, and it relied on the requirement of good faith as the statutory basis for exercising

71. U. S. Dept. of Commerce, Bureau of Census, Housing Statistics, vol. 2, part 4, table 4, p. 272 (1943). There was also a large number of small homes in which the owners did not reside in 1940. Ibid. It is likely that some of these subsequently became owner-occupied.

72. See, e.g., New York Post, Apr. 7, 1950, p. 49, col. 1. It has been reported that the average house which sold for $\$ 6,000$ in 1941 , sold for $\$ 12,475$ in 1948 , and $\$ 11,540$ in 1950. N. Y. Times, Apr. 16, 1950, $\$ 8$, p. 1, col. 8; also see The Housing Situation (The Factual Background) in U. S. Housing and Home Finance Agency 22 (June 1949).

73. A seller remaining in occupancy ran the risk of being considered not a "tenant" for eviction control purposes, and hence subject to eviction without a certificate. See Matter of Vogel v. Finkelstein, 82 N.Y.S. 2d 861 (Sup. Ct. 1948).

74. See statement of the Office of Price Administration, 14 P\&F, OPA Service 200: 372 (1944); 816 Fifth Ave. v. Leonard, 188 Misc. 728, 732 (Mun. Ct. 1947).

75. Cf. Edwards v. Finkelstein, 121 N.Y.L.J. 233, col. 5 (Sup. Ct. Jan. 19, 1950) (seller alleging that he would not have sold if had known that it would later be possible to evict him). 
control. Thus, when the landlord in Matter of Keller v. Finkelstein ${ }^{76}$ applied to the commission for a certificate under the compelling necessity exception, his application was denied because he proceeded against the tenant of a two-family house rather than the seller who was left in possession pursuant to the terms of the sale. In all other respects the applicant conformed to the requirements for a certificate. The Appellate Division, Second Department, sustained the commission's denial and stated that it was not "capricious, arbitrary or unreasonable, and the court may not substitute its judgment for that of the commission."

After the Keller decision, the same court reaffirmed its position on three separate occasions over a period of a year and a half. These cases illustrate the flexibility with which the seller-in-possession arrangement could be used to evade eviction control. In Matter of O'Neill $v$. Finkelstein, ${ }^{77}$ the purchaser bought a one-half interest in a two-family house owned by a friend. In Matter of Minio v. Finkelstein, ${ }^{78}$ a brother and sister joined to buy a one-half interest in a two-family house owned by their aunt. In both cases, as in the Keller case, the sale was preceded by a history of friction between the sellers and the remaining tenants. ${ }^{79}$ When, shortly after the sales, the buyers applied for certificates to evict the tenants, the commission denied their applications because the sellers were still in possession. The Appellate Division, Second Department, unanimously sustained both decisions. And more recently the same result was reached where not the seller, but a third party, was left in possession. In Matter of Santoro v. Finkelstein, ${ }^{80}$ the buyer agreed, at the seller's insistence, to leave the seller's son in possession of an apartment in a two-family house. Denial of a certificate for the eviction of the remaining tenant was again sustained by the Appellate Division.

It was not until the first three of these decisions had come down, that the question came before the Appellate Division, First Department. In one case, Matter of Stahl $v$. Coster ${ }^{81}$ the buyer granted the seller, as a condition to the sale of an eleven-family house, a five-year lease for the apartment occupied by the seller. The buyer then sought the eviction of one of the tenants. In a second case, Matter of Rosenbluth $v$. Finkelstein, 82 the purchaser bought a three-family house for $\$ 23,000$. The seller, at that time occupied one apartment; the seller's parents occupied a second apartment; and the third

76. 274 App. Div. 890 (2d Dep't 1948). But cf. Kole v. Kousnetz, 335 IIl. App. 123, 80 N. E. $2 d 451$ (1948).

77. 275 App. Div. 720 (2d Dep't 1949).

78. 275 App. Div. 964 (2d Dep't 1949).

79. See folios 70-77 of the record on appeal in the Keller case; folios 77-84 of the record on appeal in the O'Neill case; and folios 89-90 of the record on appeal in the Minio case.

80. 276 App. Div. 930 (2d Dep’t 1950).

81. 276 App. Div. 762 (1st Dep't 1949).

82. 276 App. Div. 115 (1st Dep't 1949). 
one was occupied by a tenant. There was a history of friction between seller and tenant. The seller refused to make the sale unless the buyer granted leases both to him and his parents. There was no evidence that the buyer was unable to buy another house adequate for his needs and free of such conditions. He chose, however, to make this purchase, and he executed the leases. He then sought to evict the tenant of the remaining apartment.

The commission denied certificates in both cases. The Appellate Division reversed both determinations, unanimously in the Stahl case and by a three-to-two vote in the Rosenbluth case. The judges dissenting in the Rosenbluth case conceded that the question of good faith was one to be decided in each case on its facts and circumstances rather than on a "general policy," and that the commission had erred on the facts of the Stahl case. They felt, however, that the Rosenbluth facts, particularly the small number of apartments in the house purchased, were significantly different and did provide a reasonable basis for the commission's denial. The commission accepted the Stahl decision ${ }^{83}$ and the distinction drawn by the Rosenbluth dissent. A regulation was issued shortly thereafter restricting the seller-inpossession principle to cases where the purchased premises contained four or less apartments. ${ }^{84}$

In the Rosenbluth case, however, an appeal was taken to the Court of Appeals. The Court affirmed ${ }^{85}$ on the ground that the "mere fact" of a seller-in-possession arrangement could not show bad faith. ${ }^{86}$ The dissent felt there was a factual basis for the commission's denial, and that it ought to be sustained "unless the courts are to undertake a plenary review of such administrative decisions." $866^{2}$ The Court's decision does not seem to rule out all possibility of a valid finding of lack of good faith based principally on the fact of a seller left in possession, provided that such a finding were based on more than that "mere fact." The Minio case ${ }^{87}$ is a possible example, where there were, in addition, such facts as the relationship between buyer and seller and conveyance of only a fractional interest.

The commission took the view that, even if the Rosenbluth case meant that the good faith rationale was not available as a means of controlling the sellerin-possession problem, some control could still be effected through the rule

83. Item IVb of Minutes of 159th Executive Commission Meeting, Dec. 6, 1949.

84. The following provision was added to the commission's Regulation I, Art. II, $\$ 5$ (b) (1) by Amendment 11, effective Feb. 10, 1950: "The Commission may deny the application of a purchaser of a building containing four (4) or less apartments, who seeks to recover possession of an apartment, other than an apartment occupied by the seller, where the apartment occupied by the seller is equally suitable and adequate for the purchaser."

85. 300 N. Y. 402,91 N. E. 2 d 581 (1950).

86. 300 N. Y. at 405,91 N. E. $2 d$ at 582.

86a. 300 N. Y. at $406-7,91$ N. E. $2 d$ at 583.

87. Note 78 supra. 
making power conferred on it by the statute to "effectuate the purposes" of the law. 88 This was the basis for the regulation it adopted after the adverse decision of the Appellate Division in the Rosenbluth case. ${ }^{89}$ The commission did not have an opportunity to clarify either the implications of the Rosenbluth decision or the efficacy of the regulation. Shortly after that decision was made, local controls were terminated in favor of a state program of controls. ${ }^{90}$

\section{Spurious Transfers}

The local law permitted issuance of a certificate only to the landlord ${ }^{91}$ of the premises, and then only for his own personal use. Consequently, as has been noted,92 a landlord was unable to evict a tenant for the benefit of a child or relative. The result was an appreciable number of conveyances to children and relatives in need of housing, followed by applications by them for certificates. Added incentive for such conveyances existed where there were strained relations between the transferor and the tenant. The commission was again faced with the problem of controlling lawful transactions whose raison d'être was to skirt the eviction controls.

These conveyances, of course, might raise issues of misrepresentation. They also presented problems of evasion. It was a simple matter for a landlord and his kin to arrange for a transfer of title, and to display all the formal indicia customarily accompanying a change in ownership. It was no more difficult to condition the transaction on some covert understanding that the conveyance would be recognized by them only to the extent and for the period necessary to prevent operation of eviction regulation. For example, they might contemplate a reconveyance to the transferor at some undetermined time in the future, after the purpose of the transfer-eviction of the tenant-had been safely accomplished. The fact that consideration had been exchanged was no obstacle, since that too might later be returned. Direct detection of such a compact was practically impossible under the best of circumstances. It was made even more difficult by the commission's heavy work load, which did not permit sleuth-like investigations to ferret out elusive understandings. It was therefore necessary in such cases to have recourse to the circumstantial process, applied in the light of the commission's experience.

SS. See Final Report 21.

89. See note 84 supra.

90. N. Y. Laws of 1950 , c. 250 . The state program discontinued federal controls as well, under the option granted by the Housing and Rent Act of 1949, 50 U. S. C. A. App. $\$ 1894(j)$.

91. The local law defined "landlord" as "An owner, lessor, assignee or any other person receiving or entitled to receive rent for the use of or occupancy of any apartment as herein defined or any agent of the foregoing." N. Y. C. ADMIN. CODE $\$$ U41-7.0(b) (4).

92. See note 58 supra. 
The two components of spurious transactions-evasion and misrepresentation-were not generally separated and identified analytically by either the commission or the courts. ${ }^{93}$ They were rather approached as an interwoven whole. Typical circumstances recognized by the lower courts in sustaining denials of certificates to transferee-relatives included: (1) Unsuccessful attempts at eviction prior to the transfer in question.94 Absence of such attempts did not necessarily prove the good faith of the transfer since, with time, landlords learned to forbear from making attempts which were likely to prove unsuccessful. (2) A close relationship between transferor and transferee.95 (3) A history of friction between transferor and tenant prior to the transfer. (4) Conveyance of only a partial interest in the premises to the transferee. $^{96}$ (5) Suspicious circumstances surrounding transferee's payment of consideration or the source of the funds allegedly used to make the payment. ${ }^{97}$ Where no consideration was paid, the transaction was particularly suspect; ;8 it was given effect, however, where the gift was clearly felt not to have been made to circumvent the law. ${ }^{99}$

Two cases of this kind came before the appellate courts. In Matter of Goodman v. Coster, ${ }^{100}$ a sale was made by a mother to two sons after she had unsuccessfully sought to evict a tenant for the benefit of one of them. She had adequate space for them in another house she owned, but did not make it available to them. The sons made a minimal cash down-payment; the sales price was lower than the cost to the mother and less than the amount at which she had listed the property with real estate agents. The Appellate Division, Second Department, ruled that these facts did not show a failure to proceed in good faith, although it sustained denial of the certificate on another ground. In Matter of Maklary $v$. Coster, ${ }^{101}$ the sale was by a father to his son. For several years the son had been in need of larger quarters, but

93. The first articulated awareness of a line between these two elements appeared in statements of Commissioner Wechsler in discussing the Britton case, infra note 99. Item IV d, Minutes of 155th Executive Commission Meeting, Oct. 25, 1949.

94. E.g., Matter of Pfister v. Finkelstein, 120 N.Y.L.J. 1292, col. 5 (Sup. Ct. Nov. 26, 1948).

95. E.g., Matter of Berlucchi v. Coster, 122 N.Y.L.J. 1280, col. 4 (Sup. Ct. Nov. 17, 1949).

96. E.g., Matter of Sefarian v. Finkelstein, 120 N.Y.L.J. 1220, col. 5 (Sup. Ct. Nov. 19, 1948).

97. E.g., Matter of Romeo v. Coster, 123 N.Y.L.J. 516, col. 7 (Sup. Ct. Feb. 9, 1950).

98. Matter of Wallach v. Finkelstein, 120 N.Y.L.J. 1332, col. 7 (Sup. Ct. Nov. $30,1948)$.

99. Matter of Britton v. Coster, 122 N.Y.L.J. 454, col. 5 (Sup. Ct. Sept. 13, 1949); In re Kapela v. Ross, 120 N.Y.L.J. 144. col. 6 (Sup. Ct. July 26, 1948). The Britton decision was acquiesced in by the commission. See Item IV d of Minutes of 155th Executive Commission Meeting, Oct. 25, 1949, supra note 93. Cf. OPA Interpretation 6(b) (1)-VI, 14 P\&F OPA SERVICE 200:2134 (1944).

100. 275 App. Div. 949 (2d Dep't 1949).

101. 276 App. Div. 1009 (1st Dep't 1950). 
apparently could not afford to buy a house. The sale was made to him shortly after the tenant had applied for a reduction in rent for failure to paint. A decision, that a finding of lack of good faith was arbitrary and capricious, was sustained without opinion by the Appellate Division, First Department. ${ }^{102}$

The basis of the Commission's finding of lack of good faith in both cases was that the transfers to the children were evasive. The reversals apparently held that evasive conduct sufficient to support a finding of bad faith was not established.103 But in neither case did the commission find that the transfers were not genuine or were less than complete, although on appeal the argument was made in the Goodman case that the mother retained real control of the premises purportedly sold, ${ }^{104}$ and in the Maklary case that the alleged conveyance from father to son was not an arms-length transaction. ${ }^{105}$ This suggests that the decisions might have been different in the presence of definitive findings by the commission on the genuineness of the transfers. It is not clear, however, that the Appellate Divisions would have considered the facts in those cases of sufficient circumstantial force to sustain such findings, and that they would not have insisted on more direct evidence of misrepresentation. ${ }^{108}$

The Court of Appeals has not passed on the questions posed by the Goodman and Maklary cases. Speculation may find the majority Rosenbluth opinion in concord with the position of those decisions on the question of evasion. That opinion offers little basis even for conjecture about the Court's attitude towards circumstantial findings, in such cases, that the transfers were not genuine. ${ }^{107}$

\section{ConcLuston}

Three interpretations of good faith are suggested by the decisions, judicial and administrative, on eviction control: (1) Good faith is established if the landlord, at the time he applies for the tenant's eviction, actually intends to occupy the quarters involved. When this intent is demonstrated, a showing of compelling necessity, plus the adequacy of the sought accommodations to relieve it, are enough to spell out good faith. (2) Good faith is not satisfied, even though there is an intent to use, unless use is also the dominant motive,

102. The fact that no appeal was attempted from this decision is not to be taken to mean that the commission agreed with it. Very shortly after it was made, the commission's life ended with the termination of local controls. See note 90 supra.

103. Cf. the comment of Commissioner Wechsler cited in note 93 supra.

104. See p. 5 of appellants' brief on appeal, supra note 100 .

105. See p. 9 of appellants' brief on appeal, stpra note 101 .

106. Cf. Matter of Vairo v. Coster, 122 N.Y.L.J. 999, col. 3 (Sup. Ct. Oct. 26, 1949).

107. Perhaps support for such findings may be found in some decisions of comparable cases made by Judge Froessel, who was on the Court of Appeals when it decided the Rosenbluth case, before his elevation to that bench. See the Pfister and Sefarian cases, supra notes 94 and 96 respectively; cf. the Kapela case, supra note 99. 
unwatered at the time of application by any substantial purpose inconsistent with the objectives of the controls. (3) Good faith is not confined, in point of time, to the period when the landlord applies for the tenant's eviction. It also governs the landlord's conduct prior to the time of application. If in the proximate past the landlord has engaged in disruptive practices or other conduct inimical to the purposes of the controls and related to his present application, he fails to show good faith even though his sole intent, at the time he makes his application, is to evict the tenant so as to use the accommodations for himself.

The first interpretation too plainly invites frustration of eviction controls, and has been rejected for that reason. ${ }^{108}$ Such support as it can muster in decided cases appears to depend on dubious construction of ambiguous language, such as that in the Rosenbluth case, that "The landlord complies with the statute's demands if he seeks the eviction with the honest intention and desire to gain possession of the premises for his own use."109 The decisions, particularly those outside New York, overwhelmingly prefer the second interpretation to the first, and it is probable that language of the type quoted actually represents a loose statement of the former. There has been little consideration outside New York of the position taken by the third interpretation. ${ }^{110}$ Its blanket rejection within that State is not to be glibly attributed to the Rosenbluth case. ${ }^{111}$

The first two interpretations place stress on deceit and misrepresentation as the crux of lack of good faith. An agency administering eviction controls of course does not need a good faith requirement to keep from being victimized by deception or fraud. ${ }^{112}$ Moreover, under the first two interpretations, the element of good faith seems to become tautological in that it adds little to the other requirements already specifically in the exception dealing with eviction for owner-occupancy. For example, if at the time he applies for the tenant's eviction the landlord misrepresents his compelling need or his dominant motive, he fails to meet the specific requirements of necessity and purpose. An interesting commentary in this regard is provided by a pair of cases decided by

108. See Snyder v. Reshenk, 131 Conn. 252, 38 A. $2 d 803$ (1944). But cf. Matter of Kelly v. Finkelstein, 120 N.Y.L.J. 406, col. 4 (Sup. Ct. Sept. 9, 1948).

109. See the Rosenbuth case, supra note 85,300 N. Y. at 405,91 N. E. $2 d$ at 582; cf. Kauffman \& Sons Saddlery Co. v. Miller, 298 N. Y. 38, 80 N. E. 2d 322 (1948).

110. Under federal controls, the question of interpreting good faith along these lines was not likely to arise. There was no compelling necessity requirement for the most part, see note 50 supra; the restriction against eviction for the benefit of children seemed lax, see note 59 supra; and there were evasion provisions which might be used in some cases, see note 5 supra.

111. The court held only that leaving a seller in possession under the circumstances of that case was not lack of good faith. This is not to say either that other practices of an evasive nature might not justify a determination of lack of good faith, or that a concept of good faith which took into account the landlord's conduct prior to the time of his application would be held per se unreasonable.

112. Cf. Finnegan v. McBride, 226 N. Y. 252, 259, 123 N. E. 374, 376 (1919). 
an appellate court in California. In Baumgarner $v$. Orton good faith was defined under OPA controls to mean "honestly, without fraud, collusion or deceit; really, actually, without pretense."113 But in Janise v. Bryan the same court later found that definition to be "obiter dictum and inaccurate"114 if it conflicted with its newly articulated conclusion that ${ }^{115}$

". . . the phrase 'in good faith' is in each case [the District of Columbia act and the Housing and Rent Acts of 1947 and 1948] immediately followed by a detailed and definite description of the purpose for which the landlord must seek possession in order to come within the exception. The phrase is not needed in any of these exceptions, to explain the description of the purpose or for mere emphasis. It can have effect, in the provisions under consideration only by regarding it as adding another element which the landlord must show, in addition to the required purpose, in order to oust his tenant."

Apart from its substantive content, application of the good faith requirement by an administrative agency has its effects on procedure. Being dependent on the particular facts, a determination on good faith may more readily be held arbitrary on judicial review unless it is made on the basis of a hearing of the parties. ${ }^{116}$ It became the commission's policy to hold hearings in all good faith cases. ${ }^{117}$ For purposes of judicial review, moreover, the record on which the determination is based must include all relevant facts, ${ }^{118}$ and be built to resist any challenge that it is not an accurate compilation of the evidence before the agency.

The commission's approach to good faith could be given substance only by application to particular cases. As the commission's experience developed, however, and persistent fact patterns emerged in good faith cases, the commission's rule making power could be exercised to articulate the effect of its approach on these patterns. An example is the provision promulgated in regard to sellers left in possession. ${ }^{119}$ Regulations, to the extent possible, put in accessible form guides to commission action. ${ }^{120}$ Moreover, when any ruling

113. 63 Cal. App. 2d 841, 844, 146 P. 2d 67, 69 (1944). This definition has been widely quoted by the courts.

114. 89 Cal. App. 2d 933, 940, 201 P. $2 d$ 466, 471 (1948).

115. Id. at $936-7,201$ P. $2 \mathrm{~d}$ at 469.

116. See, e.g., Hatfield v. Barnes, 115 Colo. 30, 33, 168 P. 2 d 552, 553 (1946). This is apart from the question whether a hearing is required as a constitutional matter.

117. See Final Report 6-8.

118. Cf. Matter of Meyer v. Finkelstein, 275 App. Div. 837 (2d Dep't 1949) ; FINAI REPORT 9.

119. See note 84 supra.

120. This was particularly important in a field relatively undeveloped and unserviced by the facilities which make rules and precedents available in more traditional areas. The commission was continually besieged by demands for information. Supplying it was not only fair to the affected parties, but was valuable in easing the problem of enforcement. See Frnal RePort 65-6. 
was challenged before the courts, it was useful to have the backing of exercise of the rule making power. ${ }^{121}$ It was, of course, necessary to be on guard against the temptation to apply such regulations mechanically. ${ }^{122}$

Taking its cue from the urgent aims and stringent character of the controls, the commission applied a broad interpretation of the meaning of good faith. In some cases that interpretation was held to exceed its statutory power. The practices complained of then had to be attacked under the broad provisions, common in eviction controls, conferring power on the executing agency to curb evasive conduct or to effectuate the purposes of the controls. Where this did not work, amendment of the underlying law became necessary.

121. Cf. Thompson v. Consolidated Gas Co., 300 U. S. 55, 69 (1937); Rogge v. United States, 128 F. 2d 800, 803 (9th Cir. 1942). The shoring-up effect undoubtedly was limited. For example, once the commission's ruling in the Roscnbluth case was termed "fiat" by the Court of Appeals, it is questionable that it would have been fiat any the loss if it had been propped by a regulation.

122. See Final Report 14. 